\title{
Liberdade, Crítica e Política: A Coerência do Pensamento de Foucault a partir do seu Debate com Habermas
}

[Freedom, Criticism and Politics: The Coherence of Foucault's Thinking from his Debate with Habermas]

\section{Elton Bernardo Bandeira de Melo»}

Resumo: Em sua trajetória, Michel Foucault produziu uma obra tão original quanto controversa, o que torna desafiadora uma compreensão consistente do seu legado. Este trabalho busca construir uma leitura dos contornos mais amplos do projeto foucaultiano, considerando passagens de sua produção intelectual, desde seu prefácio à Antropologia de Kant até suas últimas entrevistas, e tomando como referência principal suas reações às críticas a ele endereçadas por Jürgen Habermas. Para tanto, serão observadas formulações focaultianas quanto às relações entre sujeito, verdade e poder, assim como referências feitas pelo autor francês à Escola de Frankfurt. Tomando como pano de fundo as principais críticas dirigidas a sua obra, e as possíveis defesas que se lhe oferecem, sobretudo no que diz respeito às suas posições quanto à normatividade, à verdade, à liberdade e à crítica, parece ser possível posicionar-se pela coerência do pensamento de Michel Foucault, bem como pela fecundidade de seu legado para uma reflexão prática e situada sobre nós mesmos.

Palavras-chave: Foucault, Habermas, antropologia, normatividade, crítica, prática, coerência.

Abstract: In his trajectory, Michel Foucault has produced a work as original as controversial, which challenges a consistent comprehension of his legacy. This work seeks to construct a reading of the broader outlines of the Foucaultian project, considering passages of his intellectual production, from his preface to Kant's Anthropology until his final interviews, by taking as a major reference his responses to the criticisms addressed to him by Habermas. To do so, it must be seen the Foucaultian formulations regarding the relations among subject, truth, and power, as well as his references with respect to the School of Frankfurt. Taking as a background the main criticisms directed to his work, and to the possible defenses available to him, above all, with regards to his position on normativity, truth, freedom, and critique, it seems to be possible to claim for a coherence of Michel Foucault's writings, as well as for the fecundity of his legacy for a practical and situated reflection on ourselves.

Keywords: Foucault, Habermas, anthropology, normativity, criticism, practice, coherence.

\footnotetext{
${ }^{*}$ Doutorando em Sociologia pela Universidade de Brasília. E-mail: elton.bandeira@gmail.com. ORCID: https://orcid.org/0000-0001-6806-1481.
} 


\section{1 - Introdução}

Desde 1960-61, quando escreve o prefácio à Antropologia de um ponto de vista pragmático (APP), de Immanuel Kant, até sua última entrevista em 1984, Michel Foucault manteve-se, ao mesmo tempo, inspirador e controverso, aclamado e criticado. Frequentemente são apropriados ou criticados apenas fragmentos de sua obra - abordagens, conceitos ou provocações - sendo mais escassa a literatura que busca uma compreensão ampla do legado foucautiano. Este trabalho arrisca-se a identificar contornos de sua obra - sobretudo quanto a sua coerência, e à centralidade da liberdade, da crítica e da política em suas formulações -, tomando como pano de fundo as respostas de Foucault às críticas de um de seus mais célebres comentadores, Jürgen Habermas.

O debate com Habermas nunca se deu formalmente. Primeiramente, no início dos anos 80 , por não chegarem a um acordo sobre o tema do debate. Em seguida, a morte precoce de Foucault impediu-os de levarem a cabo o encontro que se travaria em torno do texto de Kant "Was ist Aufklärung?" e que estava marcado para novembro de 1984. Segundo Didier Eribon (1996, p. 169-81), o “debate Ha-
bermas/Foucault é pois um artefato, fabricado pelo contexto intelectual americano", visto que nem os ataques de Habermas a Foucault, nem a ausência de respostas do último às críticas recebidas sugerem o engajamento dos autores nessa empreitada. Mesmo assim, o diálogo entre esses autores, ainda que muitas vezes de forma indireta, bem como os debates que suscitou, tal como exposto no livro editado por Michael Kelly (1994a), "Critique and Power. Recasting the Foucault/Habermas Debate", ajudam a compreender os fundamentos das críticas e defesas interpostas por ambos, permitindo ampliar a compreensão da obra foucaultiana.

Habermas, em sua análise da obra de Foucault, identifica que a pretensa objetividade das abordagens arqueológicas e genealógicas o conduzem a certo presentismo, relativismo e parcialidade. $\mathrm{O}$ pensador alemão argumenta que Foucault, ao reduzir os aspectos internos dos conceitos de significado, de validade de verdade, e de valores, enreda-se em aporias das quais não consegue senão se esquivar. Em dois capítulos de seu O discurso filosófico da modernidade - publicado em 1985, e, portanto, após a morte de Foucault - Habermas (2000a) acusa a historiografia genealógica de Foucault de incorrer no criptonormativismo - 
uma tentativa mal sucedida de escapar aos transcendentais, e sobretudo, ao sujeito transcendental que acompanha a virada antropológica moderna (ERIBON, 1996, p. 178) - ao qual o próprio Foucault acusara as ciências humanas e suas pretensões de objetividade e de neutralidade axiológica.

A genealogia alcança um destino análogo àquele que Foucault lera nas mãos das ciências humanas: na medida em que se refugia na objetividade sem reflexão de uma descrição ascética e não participativa de práticas de poder que variam como em um caleidoscópio, a historiografia genealógica revela-se exatamente como a pseudociência presentista, relativista e cripto-normativa que não quer ser. Enquanto as ciências humanas, segundo o diagnóstico de Foucault, cedem ao irônico movimento de auto-apoderamento científico, terminando, ou melhor, agonizando em um objetivismo irremediável, na historiografia genealógica cumpre-se um destino não menos irônico: segue o movimento de uma extinção radicalmente historicista do sujeito e termina em um subjetivismo irremediável. [...] Foucault enreda-se em aporias tão logo deva explicar como deve ser entendido aquilo que o próprio historiador genealogista faz. A pretensa objetividade do conhecimento se vê, então, questionada (1) pelo presentismo involuntário de uma historiografia que permanece presa a sua situação de partida; (2) pelo inevitável relativismo de uma análise referida ao presente e que só pode ser entendida como uma empresa prática dependente do contexto; e (3) pela parcialidade arbitrária de uma crítica que não pode justificar os seus fundamentos normativos. (HABERMAS, 2000a, p. 386-7).

Foucault (1978), de outro lado, acusa Habermas, Dilthey e outros filósofos contemporâneos de incorrerem numa análise crítica que limita a própria crítica ao não reconhecer plenamente a relação interna entre legitimação do conhecimento e dominação. Também os acusa de cederem à "chantagem" das Luzes, a qual exigiria adesão 
ou recusa a seus princípios de racionalidade.

Tanto Foucault quanto os autores da Escola de Frankfurt fazem uma crítica da razão moderna, mas diferentemente dos últimos, Foucault propõe-se a olhar o presente para fazer perguntas à história orientadas aos "limites contemporâneos do necessário", o que seria uma forma de crítica permanente de nós mesmos. Essa atitude, que Foucault relaciona às Luzes, concentra-se no presente e observa os pontos específicos onde mudanças, ainda que parciais, são necessárias e possíveis. Assim, recusa projetos globais ou radicais, seja de uma nova forma de pensar, ou de uma nova sociedade (FOUCAULT, 1984a, p. 46, 1990).

Neste artigo, buscarei identificar, primeiramente, elementos que permitem sustentar uma leitura coerente de diferentes passagens da trajetória intelectual percorrida por Michel Foucault, uma vez que as principais críticas dirigidas a ele em sentido contrário parecem dissipar-se à luz de seus últimos escritos. Com isso não quero dizer, porém, que as críticas endereçadas a ele careçam de fundamento, nem que não haja posições contraditórias ou paradoxais em seus posicionamentos. A partir dessa leitura, o legado foucaultiano pode mostrar-se útil e profícuo, desde que não se busque nele respostas prontas, mas o ferramental para o exercício de uma liberdade voltada à busca por respostas particulares à questão "o que podemos e devemos fazer de nós mesmos?", quando colocada a cada uma das situações singulares suscitadas na contingência do tempo presente. Afinal, parece ter sido essa questão prática que orientou, em grande medida, as reflexões do próprio Foucault.

Após esta breve introdução, este texto está organizado de forma tal que, inicialmente, busco situar, não tanto o conteúdo da obra foucaultiana, mas aquilo que ele afirmou ter buscado em sua trajetória. Nesse percurso, a segunda seção é dedicada à Gênese e Estrutura da Antropologia de Kant, texto no qual Foucault já apresenta elementos que informarão o conjunto de sua obra. Avanço, na seção seguinte, para uma breve discussão sobre a arqueologia e a genealogia de Foucault, abordando adicionalmente suas concepções de crítica e de práticas de si - fundamentais para a leitura do legado foucaultiano aqui proposta.

Em seguida, na seção 4, ressalto questões ligadas às relações entre sujeito, saber e poder em Foucault, e exploro sucintamente algumas relações entre seu pensamento e a tradição da Escola de Frankfurt, o que se faz importante para posicioná-lo no de- 
bate com Jürgen Habermas. Na quinta seção, discuto sua normatividade e seus fundamentos éticopolíticos. Passo a abordar, na seção 6 , as principais controvérsias e críticas a ele dirigidas no âmbito de seu diálogo com Habermas, e, por fim, apresento as conclusões, pontuando elementos do pensamento foucaultiano que permitem vislumbrar sua coerência, sua riqueza prática e seus limites no que concerne à reflexão sobre nós mesmos e sobre nossa atitude no tempo presente.

\section{2 - A Antropologia de Kant e as "falsas antropologias"}

Na modernidade, a partir do século XIX, o homem coloca-se como sujeito e objeto do saber. Ele passa a ocupar o cerne da filosofia e constitui as chamadas ciências humanas apoiando-se na pergunta kantiana "o que é o homem?". É a partir dessa leitura que Foucault desenvolve, em As Palavras e as Coisas (2007), uma crítica à tentativa de produzir um saber do homem que se coloca como objeto do saber. Em seu diagnóstico, Foucault rejeita as pretensas teorias do sujeito, assim como recusa uma teoria da história fundada na ideia de origem ou em uma leitura teleológica. Para ele, esse tipo de pensamento desvia da metafísica para cair em uma filosofia transcendental não menos problemática. Ele busca, assim, afastar-se dessa filosofia, que na França se manifestava principalmente através da fenomenologia, do marxismo e do humanismo (FOUCAULT, 1984a, p. $58,1994 a)$.

De certa forma, o prefácio de Foucault à sua tradução para o francês do livro de Kant Antropologia de um Ponto de vista Pragmático (2011), complemento à sua tese de doutorado (História da loucura), escrito entre 1958 e 1960 e só publicado na França em 2008, é uma espécie de pré-história da questão o que é o homem? (HACKING, 2002). Nesse ponto, Foucault reconhece a centralidade da Antropologia no conjunto da obra de Kant, e uma relação "paradoxal" entre a Antropologia e a Crítica.

[P]or um lado a Crítica anuncia a Antropologia e lhe lá lugar no interior de uma filosofia empírica [...]. Por outro lado, a $A n-$ tropologia retoma, como se fora evidente, as grandes articulações da Crítica, e, no entanto, [...] a Crítica não tem valor de fundamento para a Antropologia [...]. (FOUCAULT, 2011, p. 77-8). 
Isso quer dizer que a $A n$ tropologia estará duplamente submetida à Crítica: enquanto conhecimento, às condições que ela fixa e ao domínio de experiência que ela determina; enquanto exploração da finitude, às suas formas primeiras e não superáveis que a Crítica manifesta. (FOUCAULT, 2011, p. 106).

Ora, esse aspecto insuperável diz respeito à finitude ${ }^{1}$, ao lugar que se torna vazio com a ausência de Deus e da metafísica, que posiciona o $\mathrm{Eu}$ enquanto limite e unidade de sintese. O Eu surge e se fixa no campo da experiência "como o fundo irredutível de um pensamento que só pode operar esta figura da experiência uma vez constituída: neste Eu o sujeito fará reconhecimento de seu passado e síntese de sua identidade". O Eu, tanto na Crítica, quanto na Antropologia “jamais pode ser objeto, mas somente forma da síntese" (FOUCAULT, 2011, p. 58-9).

Assim, a Antropologia não define o homem, ela aponta o que o homem pode e deve fazer de si mesmo para que exerça o domínio de si, para que pratique sua liberdade enquanto pertencente ao domínio do universal concreto, no qual sujeito de direito, determinado pelas regras jurídicas e submetido a elas, ou seja, enquanto "cidadão do mundo". Ressalta-se o fato de que a Antropologia não aspira um sentido universal, nem a criação de uma moralidade possível, visto que ambos já existem no homem, e manifestam-se no exercício de sua liberdade (FOUCAULT, 2011, p. 33;77; HAHN, 2010, p. 166). Também é nessa esteira que Foucault vê a Antropologia renunciar a ideia de cosmologia em favor de uma cosmopolítica.

\footnotetext{
${ }^{1}$ Foucault (2007) observa que a finitude das coisas e do ser humano na filosofia clássica, inclusive em Descartes, é tida como limite, como um obstáculo ao conhecimento, visto que "conjugado com a ideia de perfeição divina". "Isso porque o limite do conhecimento é ainda concebido como erro e metafisicamente atribuído como privação. Por sua vez, há transparência absoluta entre o sujeito que pensa e seu pensamento". Para Foucault, a Crítica de Kant opera como uma "dobradiça" entre as épistémès, onde surge um sujeito fora do espaço da Representação Clássica, fazendo desaparecer "a transparência entre ser e representação em todos os domínios". Em Kant, o Cogito passa a ser "instrumento dos conceitos do entendimento" (CANDIOTTO, 2009).
}

Apesar de finito, ele não pode ser objetivado empiricamente; ele é condição formal da experiência, mas não se encontra submetido à sua contingência. A finitude do sujeito kantiano é pensada de dentro da filosofia, na medida em que ele não está exposto à precariedade da empiricidade. Destituído de intuição intelectual, resta ao sujeito finito a intuição sensível; esta concerne à faculdade da sensibilidade, atributo do sujeito transcendental (CANDIOTTO, 2009). 
e de longe, geografia e antropologia, servindo de unidade de referência para o saber da natureza e para o conhecimento do homem, deverá dissiparse para ceder lugar a uma ideia cosmopolítica, que tem valor programático e na qual o mundo aparece antes como cidade a ser construída do que como cosmos já dado (FOUCAULT, 2011, p. 28).

As prescrições da Antropologia - e nisso consiste seu caráter pragmático - buscam ser úteis para uso na sociedade. Ela ensina o homem a reconhecer, em sua própria cultura, a escola do mundo, onde "estão em causa pretensões e astúcias, intenções dúbias e dissimulações, esforços inconfessados pelo domínio, compromissos entre paciências" (FOUCAULT, 2011, p. 38). Para Foucault, ela encontra-se em um movimento no qual natureza e liberdade estão imbricados em um uso, em uma "prática, ao mesmo tempo imediata e imperativa de uma cultura inteiramente dada" (FOUCAULT, 2011, p. 457). Ou seja, "o homem nem é homo natura, nem sujeito puro de liberdade; ele situa-se nas sínteses já operadas de sua ligação com o mundo" (FOUCAULT, 2011, p. 48). A Antropologia "não poderia deixar de ser ao mesmo tempo redutora e normativa, redutora porque não aceita do homem aquilo que ele sabe de si mesmo pelo "Selbstgefühl" [sentimento de si]", normativa, pois é, por excelência, a ciência do normal, o conhecimento de uma saúde, de uma animação do corpo desenvolvendose conforme um justo funcionamento (FOUCAULT, 2011, p. 1023).

Foucault opõe à Antropologia o surgimento de uma "falsa antropologia": aquela que apoiada na pergunta "o que é o homem?" acaba explorando esse duplo empírico-transcendental. Para Foucault, Kant mostrara a distinção entre empírico e transcendental, e, na medida em que o sujeito não é empírico, não pode se dar à experiência (MACHADO, 1981, p. 139-42). Mas essa lição foi esquecida desde início do século XIX, levando à filosofia ao seu "sono antropológico" (FOUCAULT, 2007, p. 470-4).

[É] preciso recusar todas essas "antropologias filosóficas" que se oferecem como acesso natural ao fundamental; e todas essas filosofias cujo ponto de partida e cujo horizonte concreto são definidos por uma certa reflexão antropológica sobre o homem. 
Aqui e ali está em jogo uma "ilusão" que, desde Kant, é própria à filosofia ocidental." (FOUCAULT, 2011, p. 108).

É possível reconhecer na interpretação foucaultiana da $A n$ tropologia, e na própria obra kantiana, uma série de marcas que orientam o pensamento de Foucault: rejeição à dupla empírico-transcendental; orientação prático-empírica; reconhecimento do caráter situado do homem no seu tempo e em sua história; reconhecimento tanto de agência quanto de determinações "histórico-culturais" nos indivíduos, os quais são tidos como "forma da síntese". Nesse sentido, há elementos para concordar com Diogo Sardinha (2011) quando ele assume que Foucault não apenas não rejeita a Antropologia, mas faz dela um dos principais motores de toda a sua obra, operando, fundamentalmente, a substituição do "homem" por "nós mesmos". Ademais, ele confere centralidade a uma liberdade do possivel em seus estudos e escritos, sobretudo em seus últimos trabalhos, e acentua as questões "o que fazemos" e "o que temos feito", em relação à questão "o que devemos fazer?".

Por outro lado, a interpretação de Foucault acerca do estatuto da Antropologia na obra de Kant não deixa de provocar inquietações, isto porque ele parece deslocar seu foco da analítica da verdade - a qual prepara o terreno para a elaboração da arqueologia foucaultiana - para a ontologia do presente, marcadamente em seus últimos escritos.

Foucault tem provocado muitos debates e até a hipótese de que ele teria mudado de posição, induzido pelas críticas feitas por Habermas e alguns pensadores americanos à sua noção de poder. [...] No contexto da filosofia kantiana - tal como foi interpretada pelo jovem Foucault -, na elaboração de uma ontologia do presente, a Antropologia pragmática não ocuparia necessariamente uma posição central? Na Lógica, Kant distingue um conceito escolástico - Schulbegriff - e um conceito cósmico - Weltbegriff - da filosofia, ora, esta distinção é correlata a uma outra, analisada por Foucault, entre perfeição escolástica e perfeição popular. A contraposição entre a analítica da verdade e a ontologia do presente não poderia ser vista como uma 
retomada dessas distinções kantianas? E uma "ontologia de nós mesmos" seria, em perspectiva kantiana, uma pergunta pelo significado da Aufklärung, da Revolução Francesa, mas estaria também essencialmente vinculada à questão Was ist der Mensch? (TERRA, 1997)

Embora este texto não objetive responder a questões tais como as formuladas acima por Ricardo Terra, convém sublinhar nelas certa constância das questões suscitadas pela Antropologia ao longo da obra foucaultiana, ponto que pode favorecer uma compreensão do autor francês, mas que compreensivamente escapa às formulações de Habermas, dado que o filósofo alemão não conhecera o prefácio de Foucault à Antropologia de Kant.

\section{3 - Arqueologia e Genealogia}

Abertas as vias para a crítica das falsas antropologias, Foucault passa a trabalhar em seu projeto arqueológico, cujo objetivo seria libertar a história, e mais precisamente a história do pensamento, "de sua sujeição transcendental", "de sua dominação fenomenológica”, dos laços que desde o século
XIX ligaram-na à problemática da origem e da subjetividade. Além disso, ela se orienta pela oposição: i) a "um pensamento antropológico que consagra todas as interrogações à questão do ser do homem, e permite evitar a análise da prática"; ii) a "todas as ideologias humanistas"; e, enfim, iii) ao "status do sujeito" (FOUCAULT, 1986, p. 229-32). A arqueologia não trata exatamente de estudar a história das ideias, de como elas evoluem, mas de tentar discernir como um ou outro objeto pode emergir como possível objeto de saber (FOUCAULT, 1994a, p. 121).

A arqueologia tematiza as formações discursivas, buscando explicitar suas condições de possibilidade, e tomando os enunciados como unidades elementares do discurso. Interessa-lhe, não "os discursos possíveis, discursos para os quais se estabelecem princípios de verdade ou de validade a serem realizados; ela estuda os discursos reais, que foram efetivamente pronunciados e que se apresentam como uma materialidade."(MACHADO, 1981, p. 160). Uma vez que a arqueologia aborda positividades no nível do saber, não concede privilégios para o saber especificamente científico. Com isso, o projeto arqueológico foucaultiano afasta-se da epistemologia, da gramática 
e da lógica, assim como afastase das filosofias orientadas por um dever-ser dos discursos (MACHADO, 1981).

Com sua arqueologia, Foucault evita fazer referência a um sujeito que é transcendental, assim, ele retira o homem de sua função usual de a priori, e passa a analisar a história das positividades, vista assim como "condição de realidade para enunciados" (FOUCAULT, 1984a, p. 59; 1986, p. 146). Foucault busca, com isso, "isolar as condições de emergência dos enunciados, a lei de coexistência com outros, a forma específica de seu modo de ser, os princípios segundo os quais subsistem, se transformam e desaparecem" (FOUCAULT, 1986, p. 146). Além disso, a arqueologia faz aparecerem relações entre o dizível e o visível - como diria Deleuze (1988) -, entre as formações discursivas e domínios não discursivos: instituições, acontecimentos políticos, práticas e processos econômicos. (FOUCAULT, 1986, p. 186).

Segundo Foucault, é possível se compreender a arqueologia como "a metodologia apropriada de análise de discursividades locais", ela está voltada à superfície dos discursos, ao cruzamento de séries de enunciados heterogêneas que tornam possíveis construções que em outros extratos históricos seriam indizíveis. A arque- ologia estuda os discursos numa perspectiva que não é epistemológica (no horizonte da verdade), que não busca explicitar os critérios de cientificidade aplicáveis ao julgamento de um conhecimento.

Já a genealogia pode ser entendida como a união entre saber erudito e memórias locais, a partir da qual é possível fixar um saber histórico das lutas discursivas (FOUCAULT, 1994 b, p. 22-4). Ela complementa a arqueologia ao acrescentar uma norma que explica a aparição de certos discursos, o poder. Subjacentes aos discursos verificam-se estratégias de poder - ainda que sem estrategistas. Ao levar em conta os circuitos de poder, a genealogia não se restringe à dimensão local e permite uma analítica ampliada de construções macro-históricas (e.g. dispositivos penais, racionalidade liberal de governo). Foucault busca, assim, fazer o uso tático dessa união de saberes no presente, para que "os saberes sujeitados sejam então liberados para serem trazidos a jogo" (FOUCAULT, 1994b, p. 22$4)$.

Assim, a genealogia foucaultiana pretende acolher as reinvindicações de atenção dos saberes locais, descontínuos, desqualificados, deslegitimados, contra as de um corpo de teoria unitário que os filtraria, os hierarquizaria, e os ordenaria em nome de algum sa- 
ber verdadeiro e de alguma ideia arbitrária do que constitui uma ciência e seus objetos. Com isso ela busca promover a insurreição de saberes que se opõem, não tanto aos conteúdos, métodos ou conceitos dos saberes científicos, mas a seus efeitos centralizadores de poder ligados à instituição e ao discurso científico. Noutras palavras, busca emancipar saberes históricos de uma sujeição, liberálos, isto é, torna-los capazes de se opor e lutar contra a coerção de um discurso teórico, unitário, formal, científico. Ela teria como base a reativação de saberes locais - de saberes menores na concepção de Deleuze - em oposição a hierarquização científica dos saberes e seus efeitos intrínsecos de poder (FOUCAULT, 1994b, p. 235).

É com base nessa perspectiva do projeto genealógico, não como crítica, mas como tática, que Habermas questiona a neutralidade axiológica das análises foucaultianas, cobrando-lhe um critério para justificar a disposição para essa luta, e derivando daí o fundamento para a imputação de criptonormatividade do projeto de Foucault.

[...] [S]e se trata somente de mobilizar o contrapoder, as lutas e confrontações astuciosas, coloca-se a questão de saber por que devemos resistir, em princípio, ao poder onipresente que circula nas veias e artérias do corpo da sociedade moderna, em vez de nos juntarmos a ele. Os instrumentos de luta da genealogia do saber seriam, então, supérfluos. Está claro que uma análise axiologicamente neutra de forças e fraquezas do adversário é útil para aquele que quer assumir a luta - mas por que, em princípio, lutar?: "Porque a luta é preferível à submissão? Por que resistir à dominação? Somente com a introdução de noções normativas de alguma espécie Foucault poderia começar a responder essa questão. Somente com a introdução de noções normativas ele poderia começar a nos contar o que está errado com o regime moderno de poder e conhecimento, e por que devemos nos opor a ele". (FRASER, 1981. Apud HABERMAS, 2000b, p. 397).

Segundo Jana Sawicki (1994, p. 350-3), Foucault escreveu a partir da perspectiva de um futuro historiador, para desfamiliarizar as 
práticas e as categorias do presente, para fazê-las parecer menos evidentes e necessárias. Ele teria procurado, assim, libertar um espaço para a resistência a elas, na medida em que estavam ligadas à dominação, e para a invenção de novas formas de racionalidade e experiência. Segundo Michael Kelly (1994b, p. 384), Foucault buscou compreender como as formas de racionalidade na, e através da modernidade - ou seja, do presente - tornaram-se problematizadas. Nessa leitura, a genealogia da modernidade é ferramenta para a crítica do presente como objeto, contexto e fundamento da reflexão filosófica. Thomas McCarthy (1994, p. 261), por sua vez, afirma que a genealogia é "crítica prática", guiada por interesses nas "possíveis transgressões" e transformações de restrições ditas universais e necessárias. Adotando uma atitude experimental, ela testa recorrentemente os "limites da necessidade contemporânea" para determinar "o que não é, ou o que não é mais, indispensável para a constituição de nós mesmos como sujeitos autônomos". Em todo o caso, não resta claro como essas posições poderiam suprir as lacunas levantadas por Habermas e Fraser.

Por fim, convém destacar que, para a genealogia importa conhecer quais são os efeitos de poder que circulam entre as declarações científicas, o que as constituíram, como elas eram, seu regime de poder, e como e porque em certos momentos esse regime sofre uma modificação global (FOUCAULT, 1984a, p. 55). O caráter desordenado e fragmentário da genealogia foucaultiana pode ser visto como um cuidado para que elas não fossem colonizadas, anexadas unificadas em um corpo de saber teórico científico. Por isso, Foucault não parece ter tido nenhuma intenção de prover um terreno sólido e homogêneo teoricamente para essas genealogias dispersas, para descer sobre eles do alto com algum tipo de prestígio teórico que os unisse (FOUCAULT, 1984a, p. 26).

Para Foucault, a arqueologia e a genealogia constituem uma metodologia coerente para o estudo das práticas, sendo aquilo que permite a conversão da atitude filosófica crítica (ontologia de nós mesmos) em trabalho (FOUCAULT, 1984a, p. 50). Essa posição, contudo, só parece ser esclarecida à luz de seus escritos posteriores, a partir do momento em que Foucault passa a discorrer sobre sua concepção do que seria a crítica, inspirada em uma interpretação dos textos de Kant sobre Auflklärung e Revolução. 
4 - Crítica: Luzes, Revolução e Aufklärung

Em 1978, Foucault proferiu uma conferência intitulada "Qu'est-ce que la critique? Critique et Aufklärung" (1990), onde mostrou pela primeira vez sua identificação com um conceito de crítica que perdurou até seus trabalhos finais. Ali, ele voltou-se para o exame do surgimento, no ocidente, de "uma certa maneira de pensar, de dizer, de agir", e também de "uma certa relação com o que existe, com o que se sabe, com o que se faz, uma relação com a sociedade, com a cultura, uma relação com os outros também" que ele denominou "atitude crítica".

O texto oferece um esboço da história das formas de resistência a um novo tipo de poder (inserido na noção de governamentalidade). A crítica, então seria, para Foucault, "a arte de não ser governado de tal maneira". Ela foi dirigida primeiramente contra as escrituras bíblicas e suas interpretações, e em seguida, às leis aplicadas por monarcas, patriarcas, educadores ou magistrados. Mas o foco da crítica seria, essencialmente, o conjunto das relações que conectam entre si: o poder, a verdade e o sujeito" (FOUCAULT, 1990, p. 39; SCHMIDT; WARTENBERG, 1994, p. 287-9).

Em outros termos, Foucault afirma que "a crítica é a arte da inservidão voluntária, aquela da indocilidade refletida" que visa um "desassujeitamento no interior de uma política da verdade". Ele aponta a aproximação entre essa definição e aquilo a que Kant remetera em seu texto sobre o Aufklärung, a coragem de saber ( $\mathrm{Sa}$ pere Aude!). Segundo Foucault, o que Kant entendera por crítica se aproxima de um saber até onde se pode saber, autonomamente. Para Foucault, a partir do século XIX, houve um deslocamento do Aufklärung no sentido da crítica (na acepção kantiana) - decorrente da ciência positivista, de um Estado que se colocava como razão da história e da racionalização da economia e da sociedade, e de uma ciência do Estado (FOUCAULT, 1990).

A questão do Aufklärung, qual seja, "as relações do poder, da verdade e do sujeito" é possivelmente o principal problema filosófico da modernidade, e é também o foco da prática históricofilosófica da Escola de Frankfurt, com a qual Foucault fraternizou. Para abordá-la, entretanto, Foucault, diferentemente do método da teoria crítica, propusera uma arqueologia, entendida como análise do ciclo de positividade e do nexo saber-poder que permite entender a aceitabilidade de um sistema (psiquiátrico, penal, da sexualidade etc.); uma genealogia 
que tentara restituir as condições de aparição de uma singularidade a partir de seus múltiplos elementos determinantes; e uma análise das estratégias que presidem as interações entre sujeitos (FOUCAULT, 1990; SCHMIDT; WARTENBERG, 1994, p. 292).

A partir dessa leitura, Foucault procurou desviar de uma perspectiva da legitimação (do conhecimento ou da dominação), e pensou o poder como indissociável do saber, como relação num campo de interações e estratégias. Isso possibilitaria tornar os efeitos das relações de poder frágeis e provisórios, passíveis de serem invertidos ou desfeitos a partir precisamente da decisão de não ser governado. Ao final de seu texto de 1978, Foucault sugere que seria o caso de percorrer a via que teria deslocado o Aufklärung (enquanto atitude crítica) para a questão da crítica (saber até onde se pode saber), mas agora em sentido inverso. Isso implicaria em posicionar a relação entre conhecimento e dominação justamente "a partir de uma certa vontade decisória de não ser governado, essa vontade decisória, atitude ao mesmo tempo individual e coletiva de sair, como dizia Kant, da menoridade" (FOUCAULT, 1990). Em uma entrevista em 1981, ele complementa: [u]ma crítica não é uma questão de dizer que as coisas não estão corretas como estão. É uma questão de apontar para os tipos de pressupostos, os tipos de modos de pensamento familiares, incontestáveis e não considerados, nos quais as práticas que aceitamos repousam. [...] O pensamento existe independentemente de sistemas e estruturas do discurso. É algo que muitas vezes está escondido, mas que sempre anima o comportamento do cotidiano. Há sempre um pouco de pensamento, mesmo nas instituições mais estúpidas; mesmo em hábitos silenciosos. A crítica é uma questão de iluminar esse pensamento e tentar mudá-lo. [...] Praticar a crítica é uma questão de tornar difíceis os gestos fáceis. Nessas circunstâncias, a crítica (e a crítica radical) é absolutamente indispensável para qualquer transformação. Uma transformação que permanece dentro do mesmo modo de pensamento, uma transformação que é apenas uma maneira de ajus- 
tar o mesmo pensamento aproximando-o da realidade das coisas pode ser meramente uma transformação superficial (FOUCAULT, 1998a, p. 154-5).

Em "Kant on Enlightenment and revolution" 2 (FOUCAULT, 1994c), Foucault reflete, a partir do texto de Kant "Was ist Auflklärung?", sobre o modo particular da reflexão filosófica kantiana em relação ao presente, bem como sobre a tentativa dele dar significado filosófico (teleológico) à reação contemporânea frente à Revolução Francesa. Foucault em 1983 perguntara-se se um dos papéis do pensamento filosófico desde aquele texto de Kant não seria incumbir a filosofia de descrever a natureza do presente e de "nós mesmos no presente", não como uma caracterização do que somos, mas buscando compreender porque e como "aquilo-que-é" - sobretudo o que é naturalizado, taken for granted - pode deixar de sê-lo (FOUCAULT, 1994a, p. 126).

A pergunta remetida no texto de Kant interroga o presente, do qual ele é parte, sobre o que produz sentidos para uma reflexão filosófica situada no agora. Para Foucault, essa questão inaugura uma filosofia que problematiza sua própria contemporaneidade "como um evento cujo significado, valor, particularidade filosófica é sua tarefa trazer e na qual tem que encontrar a sua própria razão de ser e os fundamentos do que diz" (FOUCAULT, 1994c, p. 140). Para Foucault, essa forma de problematizar o presente ao qual se pertence, e ao mesmo tempo o filósofo deste presente em relação àquilo que ele possui para situarse, é o que caracteriza a filosofia como discurso da modernidade.

\section{Qual é o meu presente? Qual o significado desse presente? E o que estou fazendo quando falo deste presente? Isso, parece-me, é o que significa esse novo questionamento da mo- dernidade. (FOUCAULT, 1994c, p. 141).}

Assim, o Aufklärung consistiria em um período no qual se busca responder a essas novas questões, e no qual se formula "o próprio motto, as próprias descobertas", um período que "diz o que tem

\footnotetext{
${ }^{2}$ Texto extraído da primeira aula de Foucault no curso de 1983 do Collège de France, revisado pelo autor e publicado em 'Um cours inédit', Magazine littéraire $n^{\circ}$ 207, Paris, May 1984, pp. 35 - 39. Republicado com o título "The Art of Telling the Truth" no livro Critique and Power. Recasting the Foucault/Habermas Debate, editado por Michael Kelly (1994).
} 
a fazer, tanto em relação à história geral do pensamento, quanto em relação ao presente e às formas de conhecimento, ignorância e ilusão nas quais é capaz de reconhecer sua situação histórica." (FOUCAULT, 1994c, p. 142).

Em 1798, Kant responde a uma questão que esteve presente em toda discussão filosófica alemã desde 1794. A questão era "O que é a Revolução?”. Em resposta, Kant vê no entusiasmo causado pela Revolução Francesa, um sinal de disposição moral da humanidade. Ela se manifestaria de duas formas, primeiramente, na disposição das pessoas de se concederem um sistema político que lhe agradassem; e, em segundo lugar, uma disposição de constituição política, de acordo com a moral e com a lei, que evitasse a guerra. Segundo Foucault, Kant percebera, portanto, uma relação entre a Revolução e o Aufklärung, sendo a primeira uma continuação e culminação do processo iniciado pela segunda (FOUCAULT, 1994c, p. 146).

Para Foucault, as duas questões kantianas sobre o presente "O que é Aufklärung?" e "O que é a Revolução?" continuaram sendo as duas questões-chave da filosofia moderna. Elas foram levadas adi- ante a partir de duas correntes críticas distintas legadas por Kant. A primeira, voltada para as condições de possibilidade de um saber verdadeiro, que se estende desde o século XIX, chamada de analítica da verdade. A segunda, interessada nas perguntas "o que é o nosso presente?" e "qual é o campo de possíveis experiências do presente?", chamada ontologia de nós mesmos. É nessa última corrente que Foucault enxerga de Hegel à Escola de Frankfurt, passando por Nietzsche e Max Weber, e, por fim, a si mesmo (FOUCAULT, 1994c, p. 147-8).

$\mathrm{O}$ ensaio de Kant acabou por exemplificar, para Foucault, uma maneira de fazer filosofia que poderia servir como modelo para seus próprios esforços. [...] Sua leitura de Kant sugere um lema bastante diferente do "Sapere Aude!" para a modernidade das Luzes. Para Foucault a modernidade tornou-se uma tentativa de encontrar a coragem para criar a si próprio (SCHMIDT; WARTENBERG, 1994, p. 303).

No texto "What is Enlightenment? (Was ist Aufklärung?) ${ }^{3}$,, Foucault (1984b) busca explorar as conexões entre o texto kantiano de 1784 e, de um lado, suas reflexões sobre a teleologia e a histó-

\footnotetext{
${ }^{3}$ Texto baseado em um manuscrito escrito por Foucault em francês e não publicado, editado por ele e Paul Rabinow e publicado no livro Foucault Reader (1984).
} 
ria da humanidade, de outro, suas três Críticas, cujos papeis seriam definir as condições sob as quais é legítimo o uso da razão para determinar o que pode ser sabido, o que pode ser feito e o que pode ser esperado. Nesse artigo, a hipótese de Foucault é que o texto sobre o Aufklärung se encontra no cruzamento entre as reflexões críticas e históricas de Kant, e sua novidade consistiu em apontar para reflexões sobre o "hoje" enquanto ponto de inflexão da história que motiva uma tarefa filosófica particular. É nesse sentido que Foucault enxerga ali um ponto de partida para uma atitude da modernidade. Também é sob essa lente que se torna possível traçar um paralelo entre Kant e Baudelaire. Segundo o último, o homem moderno não sai em busca de descobrir ele mesmo, seus segredos e sua verdade oculta, ele é o homem que tenta inventar-se, produzirse a si mesmo. A modernidade, assim, seria esse ethos, essa atitude de reativação permanente da crítica da sua era histórica (FOUCAULT, 1984b, p. 42).

Foucault rejeitou a ideia de modernidade como adesão a qualquer tipo de doutrina - como o humanismo -, assim como rejeitou o que chamou de "chantagem" das Luzes, a respeito da qual seria necessário se posicionar "a favor" ou "contrário". Para ele, a atitude da modernidade encerra uma questão crítica: identificar naquilo que nos é dado como universal, necessário e obrigatório, o lugar ocupado pelo que quer que seja singular, contingente, e produto de restrições arbitrárias. Assim, a crítica consistiria em analisar e refletir sobre os limites da prática que assume a forma de transgressão. Isso implica que ela não será mais praticada na busca de estruturas formais com valor universal, mas sim como uma investigação histórica sobre os eventos que nos levam a constituir a nós mesmos e a reconhecermo-nos como sujeitos do que estamos fazendo, pensando e dizendo (FOUCAULT, 1984b, p. 46).

Nesse sentido, essa crítica não é transcendental, e seu objetivo não é tornar possível a metafísica: é genealógica em seu design e arqueológica em seu método. Arqueológico - e não transcendental - no sentido de que não procurará identificar as estruturas universais de todo conhecimento ou de todas as possíveis ações morais, mas buscará tratar os casos de discurso que articulam o que pensamos, dizemos e fazemos assim muitos eventos históricos. 
E esta crítica será genealógica no sentido de que não deduzirá da forma do que somos o que é impossível para nós fazer e conhecer; mas separará, da contingência que nos fez o que somos, a possibilidade de não mais ser, fazer ou pensar o que somos, fazer ou pensar (FOUCAULT, 1984b, p. 46).

Foucault defende que essa atitude histórico-crítica deve rejeitar partir de qualquer teoria do sujeito - tal como na fenomenologia ou no existencialismo (FOUCAULT, 1997, p. 289). Assim como deve ser experimental, no sentido de testar a realidade contemporânea para compreender os pontos onde a mudança é possível e desejável, e para determinar a forma pela qual essa mudança deve ser feita. Para Foucault, isso implica em se afastar de todos os projetos que postulam ser globais ou radicais, pois isso poderia fazer retornar perigosas tradições.

Prefiro as transformações muito específicas que provaram ser possível nos últimos vinte anos em um certo número de áreas que dizem respeito a nossas formas de ser e pensar, relações com autoridade, relações entre os sexos, a maneira como nós percebemos insanidade ou doença; prefiro mesmo essas transformações parciais que foram feitas na correlação de histórico análise e a atitude prática, aos programas para um novo homem que os piores sistemas políticos repetiram ao longo de o século XX. (FOUCAULT, 1984a, p. $55)$.

De fato, Foucault recusou utopias em favor de transformações específicas, e direcionou sua atenção a investigações que possuíssem sempre um caráter local, historicamente situado, contingente, específico, o que coaduna sua posição acerca do papel do intelectual e sua aversão às "teorias totalitárias" e às soluções globais aplicadas a problemas específicos. Ele é contra qualquer totalização - o que seria a uma só vez abstrato e limitante - e buscou problemas abertos, tão concretos quanto gerais, problemas que se aproximassem da política por baixo e que dissecassem a sociedade na diagonal, problemas que fossem ao mesmo tempo constituintes de nossa história e constituídos pela história, abordados como problemas contem- 
porâneos (FOUCAULT, 1984a, p. 46-7, 1984c, p. 376). Assim, tanto sua arqueologia quanto sua genealogia orientaram-se para discursividades e saberes locais, em oposição e luta contra a coerção do discurso científico teórico, unitário e formal, conforme norma epistemológica, e teorias fundadas na verdade (BERNSTEIN, 1994, p. 228; FOUCAULT, 1980, p. 80-5, 1994b; KELLY, 1994b, p. 380).

Talvez um dos mais importantes insights de Foucault seja sua insistência em que os compromissos e imperativos teóricos de alguém sejam motivados por imperativos práticos específicos. Ele escreveu na perspectiva de um intelectual específico, envolvido em intervenções específicas. Ele estava constantemente preparado para mudar as estratégias e questionar suas posições anteriores (SAWICKI, 1994, p. 359).

Em suma, Foucault caracterizou o ethos filosófico apropriado à ontologia crítica de nós mesmos como um teste histórico-prático dos limites concretos que podemos ultrapassar, como um trabalho paciente que dá forma a nossa von- tade impaciente de sermos livres (FOUCAULT, 1984b, p. 47-50). Em uma entrevista concedida em 1983, ele reforçou que o aspecto prático do seu ethos consiste, não em aplicar ideias, mas em testálas e modificá-las. "A chave para a atitude pessoal poética do filósofo é não ficar absorvido em suas ideias, mas em sua filosofiacomo-vida, em sua vida filosófica" (FOUCAULT, 1984c, p. 374).

\section{5 - Relações entre o Saber, o Po- der e o Sujeito}

Foucault investigou ao longo de sua carreira, fundamentalmente, as relações entre saber, poder e sujeito. Em suas últimas obras, conferências e entrevistas, ele descreveu com maior clareza sua obra a partir de uma centralidade do sujeito e sua verdade - que não é a verdade-norma da epistemologia -, sendo as conexões entre saber e poder analisadas na medida em que nele incidem (FOUCAULT, 1997, 1998b). Em um ensaio escrito em 1982, ele afirma:

[m]eu objetivo, [...] tem sido criar uma história dos diferentes modos pelos quais, na nossa cultura, os seres humanos são feitos sujeitos. O meu trabalho abordou três modos de 
objetivação que transformam seres humanos em sujeitos. O primeiro é o modo de investigação que tenta dar-se o status de ciência; [n]a segunda parte do meu trabalho, estudei a objetivação do sujeito a partir do que chamo de "práticas de divisão". [...]. Exemplos são o louco e o são, o doente e o saudável, o dividido por dentro ou dividido dos outros. [...]. Finalmente, procurei estudar [...] a forma como um ser humano transforma a si mesmo em sujeito. Por exemplo, escolhi o domínio da sexualidade: como os homens aprenderam a se reconhecer como sujeitos de "sexualidade". Assim, não é poder, mas o sujeito que é o tema geral da minha pesquisa.". (FOUCAULT, 1983, p. 777-8).

Mais especificamente, a investigação foucaultiana endereçou as questões "como é que o ser humano colocou a si mesmo como objeto de saber possível?" e "a que preço os sujeitos podem falar a verdade sobre si mesmos?". Sua genealogia consiste, assim, em três domínios que só podem ser entendidos um em relação ao ou- tro, não de forma independente:

a) uma ontologia de nós mesmos em relação à verdade que nos constitui como sujeitos de saber (problema da verdade);

b) uma ontologia de nós mesmos em relação ao campo de poder que nos constitui a nós mesmos como sujeitos que agem sobre os outros; e

c) uma ontologia histórica em relação à ética pela qual nós nos constituímos enquanto agentes morais (problema da conduta individual) (FOUCAULT, 1984d, p. 351).

Ainda segundo o autor, em As Palavras e as Coisas (2007), ele buscou entender a que preço pode ser problematizada e analisada a verdade do sujeito que fala, trabalha e vive; em História da Loucura, investigou como pode ser dita a verdade do louco. O mesmo tipo de questão foi aplicado aos doentes em O Nascimento da Clínica, aos delinquentes em Vigiar e Punir e aos sujeitos que sentem prazer sexual, em A História da Sexualidade. (FOUCAULT, 1994a, p. 120-2, 1998b, p. 243).

Essas sínteses são coerentes com seus textos acerca do Aufklärung, na medida em que, em oposição a uma governamentalização que sujeita os indivíduos aos mecanismos de saber-poder, a atitude crítica (local) postulada por 
ele seria "o movimento pelo qual o sujeito se dá o direito de interrogar a verdade sobre seus efeitos de poder e interrogar o poder em relação ao seu discurso de verdade", ou, "trabalhar sobre si mesmo e responder ao próprio tempo" (BERNSTEIN, 1994, p. 232; FOUCAULT, 1990; SCHMIDT; WARTENBERG, 1994, p. 289). Aqui, cabe lembrar que, em Foucault, a noção de governo deve ser entendida no sentido amplo, como "técnicas e procedimentos destinados a dirigir a conduta dos homens. Governo dos filhos, governo das almas ou das consciências, governo de uma casa, de um Estado ou de si mesmo" (FOUCAULT, 2008a, p. 532). E, assim, a crítica - enquanto arte de não se deixar governar de certo modo encerra um exercício de liberdade.

\section{6 - Considerações em relação a} Habermas e à Escola de Frankfurt

O projeto de Foucault pode ser visto como uma investigação histórica sobre os custos de uma razão que busca a verdade sobre si, sobre os custos de constituirmonos a nós mesmos como sujeitos em situações necessariamente singulares. No âmbito desse projeto, de cuja complexidade ele tem consciência, Foucault afirma ter trazido à tona apenas alguns problemas específicos: "como se pode dizer a verdade do sujeito doente?", "qual é o preço de se analisar e de se problematizar o sujeito que fala, que trabalha e que vive, que sente prazer sexual, que pode ser julgado delinquente?" (FOUCAULT, 1994a, p. 120-1). Seu modo de enxergar o sujeito e suas verdades, radicado em uma historicidade e em articulação com a aliança "profana" entre Kant e Nietzsche, permitiu investigar como os seres humanos aplicam diferentes formas de racionalidade sobre si mesmos. Nesse ponto, seu interesse não difere do de Habermas, qual seja, "criticar as transformações históricas das formas da racionalidade moderna" (KELLY, 1994b).

Um dos afastamentos fundamentais de Foucault em relação à tradição da teoria crítica diz respeito à sua recusa da existência de uma única razão dominante (instrumental) à qual deveria ser superada por uma forma de razão mais adequada (FOUCAULT, 1994a, p. 118; MCCARTHY, 1994, p. 251).

Para mim, nenhuma forma dada de racionalidade consiste realmente em uma razão. [...] Posso ver múltiplas transformações, mas não consigo ver 
porque devemos chamar essa transformação de um colapso de razão. $\mathrm{Ou}-$ tras formas de racionalidade são criadas o tempo todo (FOUCAULT, 1994a, p. 125).

Thomas McCarthy (1994, p. 24450) discute as muitas aproximações e afastamentos entre o pensamento de Foucault e o da Escola de Frankfurt, e aponta que ambos estão muito perto no mapa das opções teóricas contemporâneas. Para ele, o pensamento de Foucault complementa o mainstream da Escola de Frankfurt ao deslocar-se do nível dos conceitos e princípios mais gerais para perseguir "singularidades transformáveis", variáveis e contingentes. A análise histórica da ascensão e função de "sistemas práticos" complementam a reflexão mais global sobre a racionalização. $\mathrm{O}$ ponto, para McCarthy, não é escolher entre Teoria Crítica e Genealogia, mas combiná-las. Para ele, suas concepções-chaves da razão, verdade e liberdade (MCCARTHY, 1994, p. 273).

Para Michael Kelly, Habermas e Foucault estão de acordo quanto à modernidade ser crítica em relação ao seu próprio presente $\mathrm{e}$ quanto a ela dever permanentemente criar suas próprias normas. $\mathrm{O}$ desacordo entre eles surge no tocante à validade e às formas de justificar essa normatividade, ou se a validade dessa normatividade é tão local quanto o contexto no qual emerge e para o qual o olhar crítico está orientado (KELLY, 1994b, p. 383).

A despeito dessa posição, não resta claro o quanto Foucault, ao alinhar-se à mesma corrente filosófica da Escola de Frankfurt quanto às preocupações com a ontologia de nós mesmos, considerase próximo a Habermas. Segundo Didier Eribon, é Foucault o autor da linhas abaixo, que opõem Habermas e a Escola de Frankfurt: o implacável escrutínio de Foucault das imposições, restrições e hierarquias que figuram nas práticas racionais desafiam os teóricos críticos para irem além do que foram na destranscendentalização de
Entre as duas guerras, a Escola de Frankfurt inquietou a filosofia de instituição, operando um deslocamento das categorias para problemas políticos contemporâneos. Ontem e anteontem, tinha-se a 
impressão de que o processo de Habermas era inverso: deslocar tudo o que acontece fora da área universitária no campo político, cultural, social para um discurso estabelecido (ERIBON, 1996, p. 171).

Segundo Eribon, apesar das inúmeras diferenças entre o pensamento de Foucault e o da Escola de Frankfurt, o primeiro reconhecera a que a última "apresentou um 'problema fundamental', o dos 'efeitos de poder, ligados ao exercício de uma racionalidade' que se forjou, histórica e geograficamente, no Ocidente, a partir do século XVI." (ERIBON, 1996, p. 175). Entretanto, os ataques de Habermas a Foucault minaram as possibilidades de um debate fecundo entre os dois filósofos. Ao associar Foucault ora a uma crítica da razão radical anarquizante, irracionalista, ora ao conservadorismo de inspiração nietzschiana que se evidenciaria na recusa ao engajamento em projetos de modernização social, não capitalistas, Habermas parece ter provocado um profundo desinteresse em Foucault em rebater as críticas habermasianas.

Ademais, o projeto de Foucault, em vários sentidos era justamente o de combater posições defendidas por Habermas, sobretudo quanto à busca por normas universais, por constantes antropológicas. Foucault acusara Habermas de se distanciar da Escola de Frankfurt ao buscar um projeto universalizante de crítica racional da racionalidade, ao invés de buscar identificar uma forma de racionalidade dominante e fazê-la aparecer como uma dentre outras formas que buscam se equivaler à razão. De fato, parece haver uma profunda divergência entre a postura dos autores frente às questões da normatividade e da universalidade de suas propostas.

$\mathrm{Na}$ verdade, são escolhas filosóficas fundamentalmente diferentes, atitudes irreconciliáveis que estão em jogo. É bastante significativo que Foucault descreva em termos de "atitude", de "ethos filosófico", de "vida filosófica" a postura de quem pretende realizar análise histórica e crítica "daquilo que somos hoje", "dos limites que nos são impostos" e da sua "ultrapassagem possível". [...] Há fortes chances de que esse ethos foucaultiano, composto de impaciência diante da realidade que nos constrange e de meticulosidade no trabalho que 
visa a minar seu pedestal de evidência, era portador de uma força progressista e emancipadora, pelo menos igual a todas essas dissertações filosóficas sobre normas, regras universais, o "sujeito" etc., de que Habermas - infelizmente - forneceu o modelo a muitos ensaístas franceses (ERIBON, 1996, p. 178).

\section{7 - Ética e Normatividade}

Em sua última entrevista Foucault afirma: "busca por uma forma de moralidade aceitável para todos, no sentido de que todos deveriam se submeter a ela, atinge me como uma catástrofe" (FOUCAULT, 1998b, p. 254). De fato, Foucault, ao longo de toda sua carreira, rejeitou o perigo das verdades universais, das teorias globais, e das prescrições normativas, às quais associara as técnicas de normalização e os dispositivos disciplinares e de sujeição. Segundo Bernstein, numa entrevista em 1983, Foucault disse que seu ponto "não é que tudo seja ruim, mas que tudo é perigoso, o que não é exatamente o mesmo que ruim. Se tudo é perigoso, então sempre temos algo a fazer." Isso seria aplicável a todo o trabalho arqueológicogenealógico, visto que suas problemáticas "destinam-se a especificar a mudança de constelação de perigos" (BERNSTEIN, 1994, p. 226-7). Consonantemente, Foucault não apenas concorda que a função crítica da filosofia é evitar os riscos do poder, como também afirma que ela deriva da injunção socrática "Cuida de si!", ou, em outras palavras, "Faça da liberdade seus alicerces, pelo domínio de si mesmo." (FOUCAULT, 1997, p. 300).

Isso, contudo, não é suficiente para fundamentar seus posicionamentos políticos: em favor da insurreição dos saberes subjugados, e em oposição às manifestações de dominação e repressão. Conforme aponta Bernstein, pelo mundo há saberes sujeitados de todos os tipos: fundamentalismos, fanatismos e terrorismos que têm seu próprio senso do que são os perigos a serem confrontados. Perigo não é algo desprovido de valor. Há de se esclarecer o porquê do perigo. Nesse ponto, Foucault não deixa claro porque alguém deveria favorecer certas formas de resistências locais frente a outras, nem porque alguém deveria escolher um lado ou outro numa resistência ou revolta localizada. E até mesmo grandes admiradores de Foucault, como Dreyfus e Rabinow, concordam que ele ficou de- 
vendo um critério para justificar porque certos perigos são piores que outros. (BERNSTEIN, 1994, p. 229). A questão dos fundamentos para justificação das causas pelas quais se vale à pena lutar, interligada com a justificação do método de luta - e daí emergem as relações entre o método arqueológico-genealógico o saber, a verdade, a ciência e a própria razão - também é, ao meu ver, o ponto principal das críticas de Nancy Fraser (1994) e Axel Honneth (1994) a Foucault.

Para tentar esclarecer como Foucault se relaciona a essas questões, convém destacar que para ele, "a liberdade, é a condição ontológica da ética. Mas ética é a forma que a liberdade assume quando é informada pela reflexão" (FOUCAULT, 1997, p. 284). Assim, a liberdade, no sentido político, é uma condição necessária para a ética. Um escravo não tem ética, assim como não tem ética o escravo de si, de seu próprio apetite, como no caso do tirano, escravo de suas próprias ambições. Isso faz com que a ética implique no exercício de uma certa dominação de si. Ele deixa claro que seus ideais se alinham à diversidade de estilos de existência, bem como à minimização das situações de dominação (FOUCAULT, 1997, p. 299, 1998b, p. 253). Isso permitiria a ampliação de jogos estratégicos (de poder) e as práticas de liberdade (FOUCAULT, 1997, p. 298-300). Ele, contudo, não prescreve uma moral, mas apenas uma ética fundada na prática refletida da liberdade. Para Foucault, "o risco de dominação ocorre apenas quando alguém se torna escravo de seus próprios desejos." (FOUCAULT, 1997, p. 288).

Dessa forma, para Foucault, o saber ${ }^{4}$ preveniria contra o abuso de poder (FOUCAULT, 1997, p. 288). Foucault cita os gregos, para quem a ética assume a forma de um ethos que pode ser observado no cuidado de si, e que também implica relações complexas com os outros, enquanto uma forma de cuidado dos outros. (FOUCAULT, 1997, p. 286). Mas, embora se perceba um postulado moral nesse comportamento do homem livre grego associado ao cuidado de si, e, por decorrência, ao cuidado com o outro, não se pode depreender que Foucault avance em prescrições para além da máxima socrática já citada (FOUCAULT, 1998b, p. 249).

Quando arguido quanto a uma

\footnotetext{
${ }^{4}$ No sentido de saber: tomar conta de si; conhecer-se ontologicamente; do que se é capaz; o que significa ser cidadão; dominar sua própria casa - oikos; o que não deve temer; o que se pode razoavelmente esperar; o que não lhe diz respeito; e finalmente, não temer a morte. [Ethics p. 288]
} 
busca de consensualidade como princípio regulatório da ação, Foucault mostra-se reticente. Ele assume a possibilidade de seu uso como princípio crítico, "uma ideia crítica para manter em todos os momentos: perguntar a si mesmo qual proporção de nãoconsensualidade está implícita em tal relação de poder, e se esse grau de dissenso é necessário ou não". Contudo, enquanto princípio moral, o máximo que ele se permite afirmar é que "talvez não se deva ser em favor da consensualidade, mas se deve ser contra a nãoconsensualidade."(FOUCAULT,

1984c). Similar hesitação se percebe em seu posicionamento acerca dos processos de liberação, ou da categoria "ideologia" (FOUCAULT, 1984a). Ele afirma ser necessário cautela com os processos de liberação, uma vez que poderiam remeter à ideia de que há uma natureza humana que deve ser emancipada, ou uma origem à qual seria possível se reconectar. Segundo ele, é preferível enfatizar as práticas de liberdade, que não decorrem diretamente de práticas de liberação. Os processos de liberação devem se orientar pela produção de práticas de liberdade. A definição das práticas de liberdade, contudo, consis- tem em um problema ético. (FOUCAULT, 1997, p. 284). Vê-se, mais uma vez, a dificuldade de extrair, do pensamento foucaultiano, uma régua moral que possa ser amplamente aplicada. Mas isso não quer dizer que ele não a tenha para si.

Ian Hacking (2002, p. 118 20) argumenta que, em alemão, o termo "sitte", utilizado por Kant em contraste ao termo "moral" usado por Nietzsche, é usualmente traduzido como "ética", mas também contempla práticas e costumes, justamente o que interessava a Foucault. Segundo Hacking, para Kant tanto uma posição ética, quanto uma moral, devem ser construídas a partir da razão privada, cujo fundamento é a ideia de liberdade. Mas esta última encontra-se fora do domínio do saber, sendo "incognoscível". Isso significa que não há nada a dizer sobre a liberdade, exceto que ela é o espaço onde construímos nossa ética e nossas vidas. Hacking prossegue: "aqueles que criticam Foucault por não nos dar uma posição a partir da qual devemos nos firmar podem começar sua crítica com Kant". Com efeito, se assumirmos que Kant concebe uma lei moral universal, ainda assim ele não aponta seu conteúdd5. Sobre esse ponto, Fou-

\footnotetext{
${ }^{5}$ Assim poderia ser interpretado o fundamento da máxima kantiana: "Age sempre segundo um princípio tal que possas querer ao mesmo tempo que ele seja uma lei universal” (KANT, 2007, p. 59).
} 
cault observa em seu prefácio à Antropologia, que Kant incorreu num tipo específico de normatividade, o de pressupor que há um certo normal do homem livre, uma normalidade no exercício da liberdade. A essa normatividade, Foucault também adere quando, por exemplo, associa o tirano àquele que não cuida de si, pressupondo um normal ético no qual o cuidado de si e a vontade de dominar os outros seria incompatível (FOUCAULT, 1997, p. 288).

James Schmidt e Thomas E. Wartenberg (1994), assim como Ian Hacking (2002), aproximam Kant e Foucault no que diz respeito a uma ética baseada no princípio de uma liberdade que permanece "necessariamente fora do domínio do saber humano". Para eles, contudo, Kant estava preocupado em construir uma norma para avaliar as máximas de ação que emergem de nossa inexplicável e inegável liberdade. E, é nesse ponto que ele se coloca a questão dos "tipos de acordos possíveis entre indivíduos livres e capazes de raciocinar [imperativo categórico]". Kant uniu a "máxima do pensamento livre de pré-julgamentos" ("pensar por você mesmo") à "máxima do pensamento ampliado" ("pensar do ponto de vista de todos os outros"). Dessa forma, pensar por si mesmo "envolveria a liberta- ção de interesses contingentes e heterônomos e atentaria para a construção de um tribunal aceitável para todos os seres livres e pensantes". Foucault parece concordar com Kant no que tange à natureza da moral, mas aliando a isso o seu historicismo, rejeita a ideia de uma lei moral nos termos kantianos. Segundo seus comentadores, "este é o passo que Foucault, como bom nietzscheano que era, não estava disposto a tomar" (SCHMIDT; WARTENBERG, 1994, p. 306-7).

\section{8 - As críticas a Foucault e suas defesas}

Inúmeras críticas são dirigidas à obra de Foucault, mas não menos são os que buscam neutralizá-las ou atenuá-las. No âmbito da bibliografia consultada para a elaboração deste texto, centrada no debate entre Foucault e Habermas, as críticas a Foucault vêm de autores como Axel Honneth, Nancy Fraser, Charles Taylor, Jana Sawicki e Richard Bernstein, dentre outros, e dizem respeito a contradições, aporias, posições paradoxais, fragilidade de sua base empírica, pretensão de neutralidade axiológica, conceitos e categorias problemáticos, falta de fundamentação para seus posicionamentos políticos normativos. Para 
os fins deste trabalho, contudo, são centrais as críticas que o próprio Habermas lhe dirigiu: criptonormativismo, presentismo, relativismo e parcialidade (HABERMAS, 2000c).

Não seria possível discutir detidamente cada uma dessas críticas, e fazê-lo não estaria alinhado ao objetivo deste texto. Cumpre salientar, entretanto, alguns pontos que servem à defesa de que há coerência nos fragmentos analisados até aqui do pensamento e da obra de Foucault, bem como para justificar certas apropriações do legado de Foucault no pensamento social. Primeiramente, compreendendo que as aporias, contradições e paradoxos, em boa medida, derivam da retórica foucaultiana, da fragmentação intencional de sua genealogia, e do próprio amadurecimento do autor, que no decorrer de sua carreira parece ter arrefecido seu estilo disruptivo, prestando-se a esclarecer - e, há quem diga, reformular - passagens controversas de seus primeiros textos.

Richard Bernstein (1994) sugere que Foucault aplicava a retórica tal como Nietzsche, para incitar seus leitores e sua plateia a "ouvir diferentes reinvindicações". Nesse sentido ele teria sido bem-sucedido. Primeiramente quebrou a lógica da filosofia moderna tradicional, obce- cada com questões epistemológicas e bases normativas, ao passo em que conseguiu mostrar ambiguidades ocultas na construção de conceitos como sujeito, liberdade e verdade, bem como o papel que desempenham nas práticas sociais. (BERNSTEIN, 1994, p. 2224). Bernstein enfatiza o fato de que a retórica disruptiva e a crítica genealógica de Foucault pressupõem e desafiam um horizonte ético-político no leitor, pois apenas implicitamente afirmam uma posição ético-política valorativa.

A retórica foucaultiana, ademais, é fértil em fomentar novas pesquisas e efetiva em revelar o lado obscuro dos constrangimentos "humanos" práticos que moldam nossas vidas e nossos corpos, bem como em mostrar como as práticas discursivas excluem, marginalizam e limitamnos. (BERNSTEIN, 1994, p. 2259). O próprio Foucault sugeriu que fizera o uso da retórica em seus primeiros livros para ofuscar o problema da subjetividade nas suas relações intrínsecas com a verdade e o poder (FOUCAULT, 1998b, p. 243). A consequência dessa retórica é a existência de vazios em meio a seus argumentos, esquivas e contradições entre falas e excertos de sua obra, onde se podem enxergar aporias.

Conquanto não tenha sido possível evitar o que Habermas cha- 
mou de "contradições performáticas", que se materializam, por exemplo, na forma como Foucault descreve o sujeito e a verdade (ora como desinteressantes e problemáticos, ora como centrais para o seu trabalho) nas diferentes fases de sua trajetória, pode-se argumentar que essas contradições perdem força frente a seus esclarecimentos tardios, que explicam o porquê de seus deslocamentos à luz de uma coerência maior, qual seja, a primazia dos efeitos práticos de seus discursos.

Ao problematizar o sujeito que diz a verdade de si, por exemplo, Foucault se esquiva de proclamar sua verdade. Sua noção de efeitos de verdade, enquanto produtos de discursos que em si não são verdadeiros ou falsos, não implica que ele rejeite a existência de verdades. E não seria demasiado ousado afirmar que ele não desvia da busca de uma certa verdade intrínseca à historiografia crítica. Ademais, quando ele se opõe à polêmica, por exemplo, um dos motivos que alega que é porque ela se oporia à verdade (FOUCAULT, 1884, p. 382). A respeito dessa delicada relação com a verdade, ele comenta:

$\mathrm{O}$ que estou tentando fazer é escrever a história das relações entre pensamento e verdade; a histó- ria do pensamento como tal é pensada sobre a verdade. Todos aqueles que dizem que, para mim, a verdade não existe são simplistas (FOUCAULT, 1998c, p. 257).

Quanto à concepção de ser humano, Foucault é acusado, e podese ver que há fundamento na acusação, de anular a agência do indivíduo que seria apenas um "corpo dócil" perpassado por uma rede de poder. Uma leitura mais ampla, entretanto, mostra que Foucault não pretendeu negar a capacidade de agência dos indivíduos. Conforme entende Jana Sawicki (1994, p. 335), "o sujeito de Foucault nem é inteiramente autônomo nem escravizado, nem é o fundador dos discursos e práticas que constituem sua experiência, nem determinado por eles". O próprio Foucault reforça essa posição, por exemplo, em seus textos sobre o exercício de si, práticas de liberdade e estratégias individuais voluntárias e intencionais (MCCARTHY, 1994).

Em relação à liberdade, para Foucault, ela é o fundamento ético que se encontra fora do domínio do cognoscível, sendo essencialmente pessoal, contingente e situado local e historicamente. Ela se manifesta no exercício de suas escolhas políticas e impulsiona sua 
crítica. Adicionalmente, convém lembrar seu argumento de que a crítica deveria ser um instrumento de luta, para pessoas que se engajam em prol de mudança nas relações de poder, donde se depreende a crítica como uma prática - sempre local e essencialmente política - que deve ser justificada em contextos específicos (KELLY, 1994b; RABINOW, 1984, p. 6). Ora, para Foucault a resistência é uma atitude crítica inseparável do poder. Poder implica em resistência, que, por sua vez, implica em liberdade. Assim, diferentemente do que Habermas poderia supor, a liberdade não enfraquece as relações de poder (KELLY, 1994b, p. 382). A liberdade pode assim ser entendida como valor basilar, e não críptico, do pensamento foucaultiano, e seu posicionamento frente a ela é firme e coerente: contrário às relações de dominação e favorável aos diferentes modos de existir, aos jogos estratégicos e às práticas de si. Mas ela não deve ser vista como algo absoluto, que se tem plenamente ou não tem. Pois, até os escravos, na medida em que podem resistir e reverter suas situações de dominação, possuem alguma liberdade. Isso posto, parece haver elementos suficientes para rejeitar que ele adira a uma espécie de criptonormativismo, algo que não fora imputado ao próprio Kant.
Quando defende o domínio de si, as práticas de liberdade, os jogos de estratégia, Foucault o faz de forma universal. Entretanto ele não acompanha Kant no passo que este último dá no sentido de buscar uma norma para a moral. Ele age politicamente na contingência, sem a necessidade de conceber uma lei universal para os comportamentos, ou uma sociedade ideal (RABINOW, 1984, p. 5). Contudo, parece pouco razoável derivar daí que ele abra qualquer espaço para que seja chamado de parcial.

Ademais, Michael Kelly argumenta com propriedade que o "presentismo" de Foucault não implica "relativismo", se isso for considerado uma negação a priori de universais. Foucault pode rejeitar a ideia habermasiana de que precisamos preservar os valores universais do Iluminismo, pois para ele, é a atitude crítica do Aufklärung (a questão da historicidade do pensamento sobre o universal) que agora deve ser mantida. Suas análises são "contra a ideia de necessidades universais na existência humana". Segundo Kelly, a razão para que ele constantemente desafie os universais, pode ser dada por Gilles Deleuze: é que eles não explicam nada e porque também são históricos; eles mesmos devem ser explicados. Para Deleuze, no âm- 
bito de instituições ou sistemas sociais (dispositivos), os universais são coordenadas ou variáveis. Assim, o que Foucault rejeita especificamente sobre os universais é seu status a-histórico, enquanto ele reconhece universais interpretados na moda deleuziana, como variáveis dentro da história. (KELLY, 1994b, p. 386).

Mas Foucault não incorre em relativismo, pois existem critérios na crítica local para fazer julgamentos sobre diferentes universais (como variáveis históricas) e formas diferentes de racionalidade. Os critérios são internos ao quadro histórico da modernidade. Por exemplo, em Vigiar e Punir (1987), quando descreve e avalia cenas de julgamentos e torturas penais do final do século XVIII, elas tendem a inspirar indignação no leitor, mas Foucault não está simplesmente tentando fazer com que nos sintamos indignados, nem está tentando ser neutro. Nenhum dos julgamentos avaliativos de Foucault, diretos ou não, pressupõe universais ou um aumento do poder social trans-histórico (KELLY, 1994b, p. 386-7). Ainda segundo Michael Kelly, quanto mais as diferentes posições de Foucault e Habermas sobre a questão dos universais são esclarecidas, menos elas diferem:

Foucault diz que os uni- versais são variáveis que devem ser criticadas constantemente, enquanto Habermas os chama de acordos (stand-ins), que são revisáveis. [...] Habermas persegue essas estratégias porque acredita que as normas universais são necessárias para a crítica em todas as práticas discursivas e concretas modernas, ao passo que os foucaultianos praticam a crítica com sucesso com os universais como variáveis (KELLY, 1994b, p. 389).

A esse respeito, cabe mencionar que em sua analítica da governamentalidade, mais especificamente quanto ao governo de populações, em sua análise das práticas estatais, a rejeição foucaultiana à análise dos universais das teorias de Estado possui certa similaridade com os alertas de Max Weber quanto aos perigos de reificação dos conceitos de entidades coletivas, tais como o Estado, a nação, a família ou o exército (FOUCAULT, 2008b, p. 4; WEBER, 2000, p. 9). Essa observação corrobora às de Michael Kelly, sobretudo quando sabido que a crítica habermasiana à abordagem de Foucault quanto aos universais fora anterior à publicação de suas genealogias das racionalidades de governo esta- 
tais.

\section{9 - Conclusões}

Foucault, desde seu prefácio à Antropologia de Kant, mostrou grande proximidade àquilo que ela representara: um conhecimento prático empírico do homem analisado em sua finitude, que rejeita a pergunta "o que é o homem?" e sua dobra empíricotranscendental; um conhecimento que busca ser útil no mundo, sem recorrer a uma norma valorativa a priori; um conhecimento orientado sobretudo à questão prática, que na versão foucaultiana assume a forma "o que podemos e devemos fazer de nós mesmos?" no nosso tempo e em nosso horizonte ético-político. Ele adentrara a década de 60 já orientado contra as teorias do sujeito, contra a hermenêutica, contra as utopias e soluções globais, e assim mantevese ao longo de toda sua trajetória. Sob esse prisma, e considerando toda sua explicação acerca da forma como articulou as etapas de seu trabalho à questão do sujeito - que produz saber sobre si, que exerce poder sobre o outro e que cria a si mesmo como sujeito - é possível, com base no que foi exposto acima, defender que seu projeto, analisado em suas diversas fases, e em seu contorno geral, se manteve coerente.

$\mathrm{O}$ debate entre Habermas e Foucault aponta muito mais afinidades entre seus objetivos e fundamentos filosóficos do se poderia supor à primeira vista, e as desavenças cumprem o papel de iluminar as diferenças, sutis e significativas, entre as duas escolas de pensamento. Curiosamente, ao tempo que Habermas acusa Foucault de, em uma suposta pretensão de plena objetividade historiográfica, buscar uma comunicação transparente, Foucault aponta em Habermas uma tentativa de dissolver as relações de poder em uma utopia de comunicação perfeita. Soa razoável, portanto, a conclusão de Michael Kelly no sentido de que ambos compartilham o projeto de uma crítica moderna, cujo desafio maior é lidar com sua autorreferencialidade (KELLY, 1994b, p. 391). Se a crítica de Foucault estaria inevitavelmente ligada a uma norma que ele buscara ocultar, posto que se trataria de uma escolha arbitrária, não teria Habermas incorrido nas mesmas aporias de que acusa Foucault, ao buscar fundamentar suas normas em uma racionalidade igualmente contingente e situada de onde ele busca derivar universais?

Nesse ponto, Foucault toma o exercício de si, como prática de liberdade, para fundamentar sua 
ética ao tempo em que rejeita qualquer norma universalizante. Ademais, Foucault não concordou com a teoria crítica no sentido de que haveria uma razão a ser superada. Muito menos esteve interessado em uma norma ideal de conduta, em um modelo de sociedade ou em uma teoria global para fenômenos do presente. Pelo contrário, ele se opôs energicamente a tudo isso e a tudo o que a isso se assemelhasse. Assim, não é de se estranhar que as categorias foucaultianas se mostrem pouco úteis para essas finalidades. Em posição diametralmente oposta, Habermas parece buscar dissolver os riscos de uma imposição valorativa particular a partir de uma ética fundada na ação comunicativa, mas, por outro lado, sustenta-a como norma racional aplicável a toda comunidade.

Nesse sentido, Habermas, Honneth e Fraser mostram certa propriedade quanto ao fato de alguns dos conceitos de Foucault serem problemáticos e de que seu pensamento não constitui um terreno seguro para a construção de uma organização social, para uma teoria de justiça, ou do Estado. Uma vez que o objetivo de Foucault era totalmente outro, possivelmente suas ferramentas de análise não serão as mais potentes para ques- tões concernentes às interpretações sociais globais, às formas de ordenamento jurídico, à norma para emancipação de grupos sociais, etc. Isso não significa, entretanto, que seus conceitos e métodos não possam ser apropriados com sucesso em diversos contextos práticos locais, sobretudo no que se refere à produção de resistências e insurgências em situações de dominação e opressão.

Por fim, a filosofia de Foucault remete-nos a um exercício profundo reflexão sobre todas as formas de pensar que estão naturalizadas em nosso presente, e cuja história deveríamos investigar para alargar nossa visão quanto ao que podemos e devemos fazer de nós mesmos, no nosso tempo, em nosso local, a partir de um horizonte éticopolítico que compete a cada um construir, assentando-se nas práticas de si. Além do mais, parece evidente que o cerne do legado de Michel Foucault é sua orientação prática e empírica engajada, vocacionada para testar limites - inclusive os próprios limites do pensável, do dizível e praticável -, enfim, para lutar contra o que quer que afronte a liberdade de exercitarmos aquilo que queremos fazer de nós mesmos e para nós mesmos, aqui e agora. 


\section{Referências}

BERNSTEIN, R. Foucault: Critique as a Philosophic Ethos. In: KELLY, M. (Ed.). Critique and power: recasting the Foucault/Habermas debate / edited by Michael Kelly. Cambridge, Massachussets and London: The MIT Press, 1994. p. 211-241.

CANDIOTTO, C. Foucault, Kant e o lugar simbólico da Crítica da Razão Pura em As Palavras e as Coisas. Kant e-prints. Campinas, 2. v. 4, n. 1, p. 16, jun. 2009.

DELEUZE, G. Foucault. São Paulo: Editora Brasiliense, 1988.

ERIBON, D. Michel Foucault e seus contemporâneos. Rio de Janeiro: Jorge Zahar, 1996.

FOUCAULT, M. Polemics, Politics, and Problemizations. In: RABINOW, P. (Ed.). The Foucault reader. New York: Pantheon Books, 1884. p. 381-90.

FOUCAULT, M. Power/knowledge. Selected interviews $\mathcal{E}$ other writings. 1972 - 1977. New York: Pantheon Books, 1980.

FOUCAULT, M. The Subject and Power. In: DREYFUS, H.; RABINOW, P. (Eds.). Michel Foucault: Beyond Structuralism and Hermeneutics. Chicago: The University of Chicago Press, 1983. p. 208-226.

FOUCAULT, M. Truth and Power. In: RABINOW, P. (Ed.). The Foucault reader. New York: Pantheon Books, 1984a. p. 51-76.

FOUCAULT, M. What is Enlightenment? In: RABINOW, P. (Ed.). The Foucault reader. New York: Pantheon Books, 1984b. p. 32-50.

FOUCAULT, M. Politics and Ethics: An Interview. In: RABINOW, P. (Ed.). The Foucault reader. New York: Pantheon Books, 1984c. p. 373-80.

FOUCAULT, M. On the Genealogy of Ethics: An Overview of Work in Progress. In: RABINOW, P. (Ed.). The Foucault reader. New York: Pantheon Books, 1984d.

FOUCAULT, M. A Arqueologia do Saber. Rio de Janeiro: Forense Universitária, 1986.

FOUCAULT, M. Vigiar e Punir: nascimento da prisão. Petrópolis: Vozes, 1987.

FOUCAULT, M. Qu'est-ce que la critique? Critique et Aufklärung. Bulletin de la Societé Française de philosophie, v. 82, n. 2, p. pp 35-63, 1990.

FOUCAULT, M. Critical Theory / Intellectual History. In: KELLY, M. (Ed.). Critique and power: recasting the Foucault/Habermas debate 
/ edited by Michael Kelly. Cambridge, Massachussets and London: The MIT Press, 1994a. p. 109-138.

FOUCAULT, M. Two Lectures. In: KELLY, M. (Ed.). Critique and power: recasting the Foucault/Habermas debate / edited by Michael Kelly. Cambridge, Massachussets and London: The MIT Press, 1994b. p. $17-46$.

FOUCAULT, M. The Art of Telling the Truth. In: KELLY, M. (Ed.). Critique and power: recasting the Foucault/Habermas debate / edited by Michael Kelly. Cambridge, Massachussets and London: The MIT Press, 1994c. p. 139-148.

FOUCAULT, M. The Ethics of the concern of the self as a practice of freedom. In: RABINOW, P. (Ed.). Ethics. New York: The New Press, 1997. p. 281-301.

FOUCAULT, M. Practicing Criticism. In: KRITZMAN, L. D. (Ed.). Michel Foucault:politics philosophy culture interviews and other writings 1977-1984. New York: Pantheon Books, 1998a. p. 152-161.

FOUCAULT, M. The Return of Morality. In: KRITZMAN, L. D. (Ed.). Michel Foucault: Politics philosophy culture interviews and other writings 1977-1984. New York: Routledge, Chapman \& Hall, 1998 b. p. 242-254.

FOUCAULT, M. The Concern for Truth. In: KRITZMAN, L. D. (Ed.). Michel Foucault:politics philosophy culture interviews and other writings 1977-1984. New York: Routledge, Chapman \& Hall, 1998c. p. 255-270.

FOUCAULT, M. As palavras e as coisas. São Paulo: Martins Fontes, 2007. FOUCAULT, M. Segurança, território, população. São Paulo: Martins Fontes, 2008a.

FOUCAULT, M. Nascimento da biopolítica. São Paulo: Martins Fontes, 2008b.

FOUCAULT, M. Gênese e Estrutura da Antropologia de Kant. São Paulo: Edições Loyola, 2011.

FRASER, N. Foucault on Modern Power: Empirical Insights and Normative Confusions. Praxis International, v. 1, p. 283, 1981.

FRASER, N. Michel Foucault: A "Young Conservative"? In: KELLY, M. (Ed.). Critique and power: recasting the Foucault/Habermas debate / edited by Michael Kelly. Cambridge, Massachussets and London: The MIT Press, 1994. p. 185-210.

HABERMAS, J. O discurso filosófico da modernidade. São Paulo: Martins Fontes, 2000a. 
HABERMAS, J. Aporias de uma teoria do poder. In: O discurso filosófico da modernidade. São Paulo: Martins Fontes, 2000b. p. 373-410.

HABERMAS, J. Aporias de uma teoria do poder. In: $O$ discurso filosófico da modernidade. São Paulo: Martins Fontes, 2000c. p. 373-410.

HACKING, I. Self-Improvement. In: Historical Ontology. Cambridge: Harvard University Press, 2002. v. 2p. 115-120.

HAHN, A. A função da antropologia moral na filosofia prática de Kant. Campinas, Universidade Estadual de Campinas, 2010.

HONNETH, A. Foucault's Theory of Society: A Systems-Theoretic Dissolution of the Dialectic of Enlightenment. In: KELLY, M. (Ed.). Critique and power: recasting the Foucault/Habermas debate / edited by Michael Kelly. Cambridge, Massachussets and London: The MIT Press, 1994. p. 157-184.

KANT, I. Fundamentação da metafísica dos costumes. Lisboa: Edições 70, 2007.

KELLY, M. (ED.). Critique and Power Recasting the Foucault / Habermas Debate. Cambridge, Massachussets and London: The MIT Press, 1994a.

KELLY, M. Foucault, Habermas, and the Self-Referentiality of Critique. In: Critique and power: recasting the Foucault/Habermas debate / edited by Michael Kelly. Cambridge, Massachussets and London: The MIT Press, 1994b. p. 365-400.

MACHADO, R. Ciência e saber: a trajetória da arqueologia de Michel Foucault. Rio de Janeiro: Edições Graal, 1981.

MCCARTHY, T. The Critique of Impure Reason: Foucault and the Frankfurt School. In: KELLY, M. (Ed.). Critique and power: recasting the Foucault/Habermas debate / edited by Michael Kelly. Cambridge, Massachussets and London: The MIT Press, 1994. p. 243-282.

RABINOW, P. Introduction. In: RABINOW, P. (Ed.). The Foucault reader. New York: Pantheon Books, 1984. p. 3-30.

SARDINHA, D. Kant, Foucault, e a Antropologia pragmática. Kant eprints, v. 6, n. 2, p. 43-58, 2011.

SAWICKI, J. Foucault and Feminism: A Critical Reappraisal. In: KELLY, M. (Ed.). Critique and power: recasting the Foucault/Habermas debate / edited by Michael Kelly. Cambridge, Massachussets and London: The MIT Press, 1994. p. 347-364.

SCHMIDT, J.; WARTENBERG, T. E. Foucault's Enlightenment: Critique, Revolution, and the Fashioning of the Self. In: KELLY, M. (Ed.). Critique and power: recasting the Foucault/Habermas debate 
/ edited by Michael Kelly. Cambridge, Massachussets and London: The MIT Press, 1994.

TERRA, R. R. Foucault leitor de Kant: da antropologia à ontologia do presente. Analytica, v. 2, n. 1, p. 15, 1997.

WEBER, M. Economia e Sociedade: fundamentos da sociologia compreensiva vol.1. Brasília: Editora UnB, 2000.

Recebido: $15 / 02 / 2019$

Aprovado: $19 / 04 / 2019$

Publicado: 13/05/2019 
